\title{
A hidradenitis suppurativa nőgyógyászati vonatkozásai
}

\author{
Kiss Norbert dr. ${ }^{1}$ - Plázár Dóra ${ }^{1}$ - Lörincz Kende dr. ${ }^{1}$ \\ Bánvölgyi András dr. ${ }^{1}$ - Valent Sándor dr. ${ }^{2}$. Wikonkál Norbert dr. ${ }^{1}$
}

${ }^{1}$ Semmelweis Egyetem, Általános Orvostudományi Kar, Bőr-, Nemikórtani és Bőronkológiai Klinika, Budapest

${ }^{2}$ Semmelweis Egyetem, Általános Orvostudományi Kar, II. Szülészeti és Nőgyógyászati Klinika, Budapest

\begin{abstract}
A hidradenitis suppurativa (HS) a szőrtüszők krónikus és rekurráló gyulladásos betegsége, mely elsősorban az apokrin verejtékmirigyekkel borított bőrterületeket érinti. A HS időszakosan fellángoló, súlyos életminőség-romlással járó kórkép, mely jellemzően a reproduktív korú fiatal felnőtteket, a 20-40 éves korosztályt érinti. Nőkben akár 3-szor gyakrabban fordul elő. Klinikai megjelenésére jellemzók a fájdalmas, hegesedő csomók és abscessusok, melyek leginkább a hónaljban, a genitalis régióban, az ágyéknál, az emlőkön, illetve a perianalis régióban fordulnak elő. A HS nagyon gyakran jár együtt igen nagy mértékű fájdalommal, bűzös váladékozással, melyek együttesen jelentős pszichológiai stresszhez, szociális stigmához vezetnek. Célunk elsősorban az volt, hogy felhívjuk a figyelmet erre az egyelőre kevéssé ismert betegségre, különösen a nőgyógyász kollégáink körében, ugyanis - a betegség típusos lokalizációja miatt - a betegek sokszor őket keresik fel először tüneteik jelentkezésekor. A kórképet a klinikai tünetek alapján a Hurley-féle stádiumbeosztással osztályozzuk. A HS kezelésével kapcsolatban számos klinikai vizsgálat történt az utóbbi években. Több gyógyszer jó terápiás hatásáról is beszámoltak, azonban az esetek többségében a terápia többszöri váltására is szükség van. A kezelés kiválasztásakor azonban nem elég a HS súlyossága alapján mérlegelnünk, ügyelnünk kell a beteg egyéb társbetegségeire, valamint egy esetlegesen fennálló terhességre, ilyenkor ugyanis nem minden elérhető szer választható. A HS nemcsak bőr-, de nőgyógyászati szempontból is fokozott odafigyelést és körültekintést igénylő betegség. Megfelelő kezeléssel ugyanakkor hosszan tartó remisszió érhető el.
\end{abstract}

Orv Hetil. 2019; 160(8): 291-299.

Kulcsszavak: hidradenitis suppurativa, nőgyógyászat, terápia

\section{Gynecological aspects of hidradenitis suppurativa}

Hidradenitis suppurativa is a chronic inflammatory disease of the hair follicles, usually presenting after puberty on the apocrine gland-bearing areas of the body. It usually flares up periodically and can lead to a severe condition affecting the 20-40-year-old childbearing age group. HS occurs more commonly in women. The main clinical features consist of painful, cicatrizing nodules and abscesses which develop mostly in the axillary, inguinal, genital and perianal regions and also on the breasts. HS is often accompanied by severe pain and malodorous discharge, both of which cause significant psychological stress and social stigma. Our main aim with this review paper is to highlight the gynecological aspects of this disease, as many times - due to the typical localization of the disease - patients seek gynecological care first when they experience the first symptoms of this disease. The most important classification of HS is the Hurley scale, which is based on the severity of the clinical symptoms. In recent years, numerous clinical trials have been conducted to seek optimized care of HS patients. Several drugs are used for the treatment of HS, but in most cases, the treatment has to be switched many times. It is of great importance to carefully follow comorbidities and possible pregnancies as in these cases, careful selection of treatment is required. Thus, HS is not only a dermatological, but also a gynecological disease. With an appropriate treatment and follow-up, the disease can be effectively handled.

Keywords: hidradenitis suppurativa, gynecology, therapy

Kiss N, Plázár D, Lőrincz K, Bánvölgyi A, Valent S, Wikonkál N. [Gynecological aspects of hidradenitis suppurativa]. Orv Hetil. 2019; 160(8): 291-299.

(Beérkezett: 2018. szeptember 27.; elfogadva: 2018. október 21.) 


\section{Rövidítések}

$\mathrm{ANA}=($ antinuclear antibody $)$ antinukleáris ellenanyag; $\mathrm{BMI}=$ (body mass index) testtömegindex; $\mathrm{COX}=($ cyclooxygenase $)$ ciklooxigenáz; DHEAS = (dehydroepiandrosterone sulfate) dehidroepiandroszteron-szulfát; G6PD $=$ (glucose-6-phosphate dehydrogenase) glükóz-6-foszfát-dehidrogenáz; GnRH $=($ gonadotropin-releasing hormone $)$ gonadotropinfelszabadító hormon; HIV = humán immundeficientiavírus; HPV = humán papillomavírus; HS = hidradenitis suppurativa; MRI = (magnetic resonance imaging) mágnesesrezonancia-vizsgálat; NSAID $=$ (nonsteroidal antiinflammatory drug) nemszteroid gyulladáscsökkentő gyógyszer; NYHA = (New York Heart Association) New York-i Szívbetegséggel Foglalkozó Társaság; STEEP $=$ (skin-tissue-sparing excision with electrosurgical peeling) bőrszövetet kímélő excisio elektrosebészeti hámlasztással; $\mathrm{TNF} \alpha=$ tumornekrózisfaktor-alfa; $\mathrm{TRH}=$ (thyrotropinreleasing hormone) tireotropinfelszabadító hormon; TSH = (thyroid-stimulating hormone) thyreoideastimuláló hormon

A hidradenitis suppurativa (HS) a szőrtüszők krónikus és rekurráló gyulladásos betegsége, mely elsősorban az apokrin verejtékmirigyekkel borított bőrterületeket érinti. Korábban elterjedt neve az acne inversa, mely elnevezés nem túl szerencsés, ugyanis nem eltérő testtájakon kialakuló acnéról van szó [1, 2]. A HS időszakosan fellángoló, súlyos életminőség-romlással járó kórkép, mely jellemzően a reproduktív korú fiatal felnőtteket, a 20-40 éves korosztályt érinti. Nőkben akár háromszor gyakrabban fordul elő, s gyakran a betegek először nőgyógyászhoz fordulnak panaszaikkal $[2,3]$. A HS klinikai megjelenésére jellemzők a fájdalmas, hegesedő csomók és abscessusok, melyek leginkább a hónaljban, a genitalis régióban (1. ábra), az inguinalis régióban (2. ábra), a perianalis régióban (3. ábra), illetve az emlőkön (4. ábra) fordulnak elő. A HS nagyon gyakran jár együtt igen nagy mértékü fájdalommal, odorosus váladékozással, melyek együttesen jelentős pszichológiai stresszhez, szociális stigmához vezetnek. Ehhez nagyon gyakran társul a nehezen tolerálható fájdalom és hegesedés miatti mozgás- és munkabeli akadályozottság is [4]. Mivel a HS gyakran jelentkezik submammalisan, illetve a nemi szervek területén, a betegek gondozása nemcsak bőrgyógyászati, hanem nőgyógyászati szempontból is fokozott odafigyelést és körültekintést igényel [1]. Megfelelő kezeléssel a betegség tünetei jól karbantarthatók, hosszan tartó remisszió érhető el. Ennek elmaradása vagy helytelen kezelés alkalmazása esetén a tünetek súlyosbodhatnak, sőt a hosszan tartó krónikus gyulladás talaján laphámrák is kialakulhat [2].

A HS-t először egy francia anatómus és sebész, Velpeau írta le 1839-ben. A kórkép az úgynevezett follicularis okklúziós tetrád tagja, amely a HS-n kívül magában foglalja az acne conglobatát, a disszekáló cellulitist és a pilonidalis cisztát. A HS számos, apokrin miriggyel fedett bőrterületen előfordulhat, predilekciós helyei azonban nemenként különböznek. A perianalis érintettség gyakoribbnak tûnik a férfiakban, míg a genitofemoralis HS a legtöbbször nökben fordul elö [5].
Európai populációkban végzett dán és francia tanulmányok szerint a HS prevalenciája megközelítőleg 1\%. Ez az érték közelít a pikkelysömör előfordulási gyakoriságához, ami a fejlett államokban $1-4 \%$ közé tehető. A hasonló prevalencia ellenére a HS lényegesen kisebb figyelmet kap, és felismerése sajnos a gyakorlatban sokszor a mai napig elmarad $[4,6]$.

\section{A betegség súlyossága, stádiumok}

A HS szembetúnő sajátossága az apokrin mirigyekkel fedett bőrterületek fájdalmas, duzzadt csomói. Ezek sú-
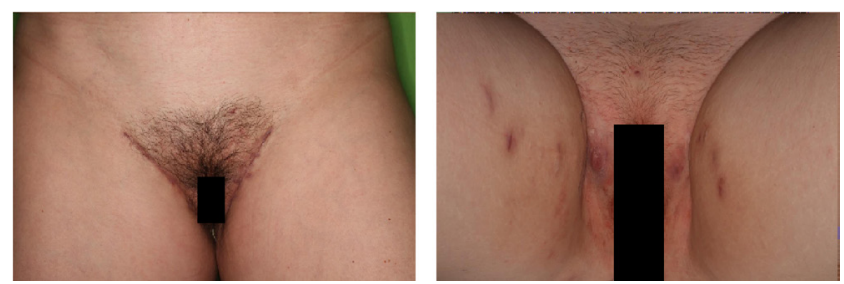

1. ábra Genitalis hidradenitis suppurativa. Hurley I. (bal) és Hurley II. (jobb) stádium
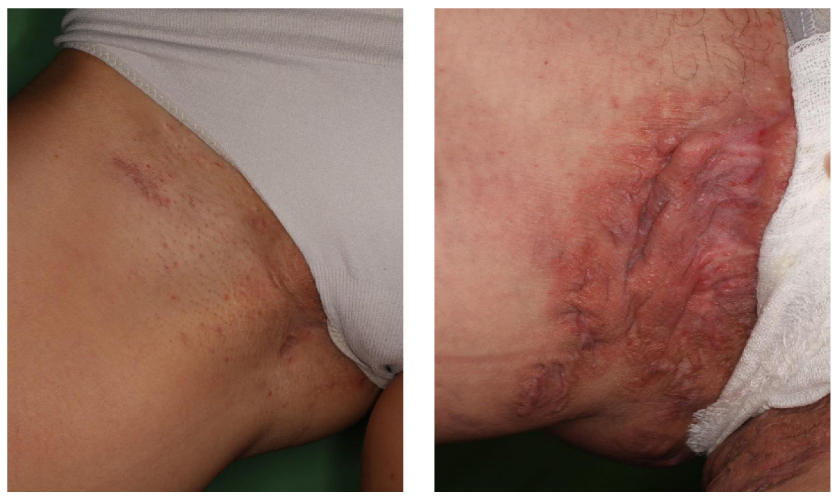

2. ábra Inguinalis hidradenitis suppurativa. Hurley I. (bal) és súlyos, Hurley III. (jobb) stádium
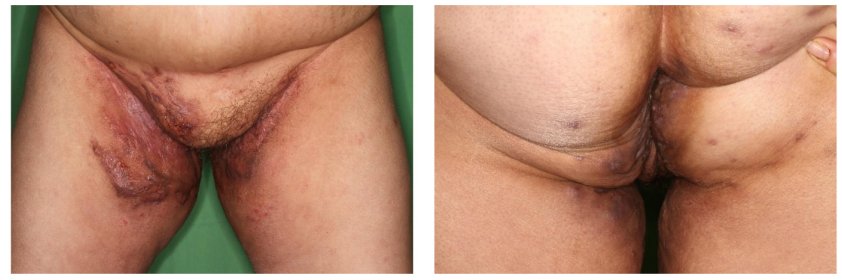

3. ábra

Inguinalis hidradenitis suppurativa, súlyos, Hurley III. stádium (bal). Analis hidradenitis suppurativa, Hurley II. stádium (jobb)
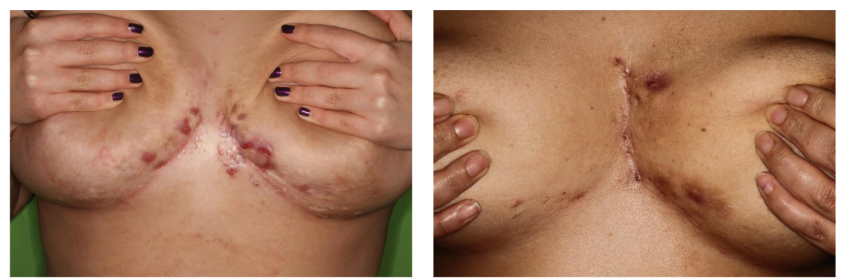

4. ábra Submammalis hidradenitis suppurativa, Hurley III. (bal) és Hurley II. (jobb) stádium 
lyossága eltérő lehet, a lokális gyulladáson kívül tályogok, fisztulák, nagyfokú hegesedés is uralhatja a klinikai képet. A HS súlyosságának leírására ma a klinikumban a Hurley-féle beosztást használjuk, melyet a névadó 1989. ben készített el. E szerint megkülönböztetünk Hurley I. (enyhe), Hurley II. (közepes) és Hurley III. (súlyos) stádiumot [7].

I. stádium: egy vagy több izolált abscessus kialakulása, sinusképződés és -hegesedés nélkül. Ez a leggyakoribb forma, a HS-betegek $68 \%$-a tartozik ebbe a csoportba.

II. stádium: egy vagy több - az utóbbi esetben jól elkülöníthető - rekurrens abscessus jelenléte sinusképződéssel. Hegesedés is előfordulhat. Az esetek 28\%-ára jellemző.

III. stádium: diffúz, vagy közel diffúz érintettség és többszörös összekapcsolódó sinusjáratok vagy abscessusok, egy vagy több apokrin régió területén. Jellemző a kifejezett hegesedés. Ez a súlyos forma mindössze a betegek 4\%-ánál észlelhető [7].

\section{Rizikófaktorok}

Számos tanulmány született arról, hogy az elhízás, a pozitív családi anamnézis, illetve a dohányzás rizikófaktornak számít a betegség megjelenésében. A testtömegindex (body mass index, BMI) értéke nemcsak a HS előfordulásával, de súlyosságával is összefüggésbe hozható. Canoui-Poitrine és mtsai erôs kapcsolatot mutattak ki a HS súlyossága és a BMI között. Minden egység BMInövekedés átlagosan 1,12-es rizikónövekedést jelent a HS kialakulásában egy klinikai vizsgálat szerint [4]. Így a kismértékben nagyobb BMI is jelentős mértékben súlyosabb tünetekkel járó HS-val hozható összefüggésbe. Egy másik vizsgálatban a BMI szerint normális, túlsúlyos és obes alcsoportokra osztott páciensekben azt az eredményt kapták, hogy az obes páciensek között jelentősen nagyobb arányban fordult elő a HS súlyos (Hurley III.) formája, mint a túlsúlyosakban [6]. Ez az összefüggés igaz volt akkor is, ha a túlsúlyos és a normáltestsúllyal rendelkezőket hasonlították össze: közülük a túlsúlyos betegek szenvedtek nagyobbrészt súlyos HS-ban $[6,8]$. Egy olyan tanulmány, amelyben a részt vevő HS-páciensek között a kontrollcsoporthoz képest nagyobb arányban fordult elő metabolikus szindróma társbetegségként, arra enged következtetni, hogy a metabolizmus eltérései nagymértékben hozzájárulnak a HS kialakulásához, különösen a fiatalabb korosztályokban. Így kezelőorvosként tehát fontos a beteg számára hangsúlyoznunk azt, hogy megfelelő diétával és rendszeres testmozgással a betegség lefolyása jelentősen javulhat [9].

Háromból egy HS-beteg esetében pozitív a családi anamnézis, így a betegség kialakulásában a genetikai háttérnek fontos szerep tulajdonítható. A HLA-B- és a HLA-DR-génnel összefüggést nem találtak. Egy atípusos és különösen súlyos HS-fenotípusban a gamma-szekretáz-gén szerepére találtak adatokat. A vizsgálatok ellenére egyelőre nem találtak olyan génpolimorfizmust, amely egyértelmúen azonosítható lenne a HS genetikai hátterében. HS gyakran társul gyulladásos bélbetegségekkel, spondyloarthropathiákkal, illetve pyoderma gangrenosummal $[4,6,10]$.

Egy német tanulmány szerint dohányzókban közel 10-szeres a HS előfordulása azokhoz képest, akik már nem vagy soha nem is dohányoztak [4]. Hasonlóképpen, egy lengyel felmérés a dohányzást az egyik legjelentősebb oki tényezőnek tartja a HS kialakulásában. Ezzel ellentétben egy francia tanulmány semmiféle összefüggést nem talált a dohányzás és a HS súlyossága között. Arról még nem rendelkezünk világos adattal, hogy a dohányzás abbahagyása mennyiben befolyásolja a HS lefolyását $[4,6,8]$. Így bár a dohányzás szerepe még nem pontosan tisztázott HS-ban, ennek ellenére fontos, hogy felhívjuk betegeink figyelmét a dohányzás elhagyására [11].

\section{A HS endokrinológiai vonatkozásai}

A HS hátterében a hypothalamo-hypophysealis tengely múködési zavarát is feltételezik. Ezt igazolja, hogy a kombinált TRH és GnRH hormonokra adott prolaktinés TSH-emelkedés szignifikánsan nagyobb HS-betegek esetében [12]. Az ösztrogén, a progeszteron, a tesztoszteron, a DHEAS, a T3 és a T4 plazmaszintjében nincs eltérés HS-betegekben az egészséges populációhoz képest. Így valószínúsíthető, hogy HS-ban a különböző visszacsatoló mechanizmusok zavara van jelen, és nem az elülső hipofízislebeny specifikus sejtjeinek zavara áll a háttérben [12-14].

Habár HS-betegekben nem jellemző az emelkedett szérumtesztoszteron-szint, nincs kizárva, hogy az androgéntúlsúly szerepet kap a betegség patomechanizmusában. A véletlenszerüen mért bazális tesztoszteronszint félrevezető lehet, ugyanis a normális összhormon-koncentráció a vérben nem zárja ki a biológialiag aktív hormonkomponens meglétét [15]. Az acnéban szenvedő betegek $80 \%$-ában a DHEAS szintje emelkedett. Ez segíthet elkülöníteni óket a HS-ban szenvedő betegektől, akikben ez az érték a legtöbbször a normálértéken belüli tartományba esik [15-17].

A terhesség és a szülés alatt a HS tünetei az esetek többségében javulnak, post partum a betegség gyakorta ismét fellángol. Ezt korábban a vérben kialakuló magas ösztrogénszintnek tulajdonították, ma már azonban ismert, hogy terhességben számos egyéb változás is megfigyelhető, így a pontos magyarázathoz további vizsgálatokra is szükség lenne [18]. A betegség természetes lefolyása és ciklikus változásai egybeesnek a menstruációs ciklussal. Amikor az ösztrogén szintje magas, a betegek állapota javulást mutat, míg menstruáció alatt, amikor az ösztrogénszint jelentősen lecsökken, a betegség fellángol [19]. Ez a menstruációasszociált fellángolás a betegek jelentős részében megfigyelhető. A HS-betegek esetén jellemző, hogy ciklusuk rövidebb, a menses azonban több napig tart. Lehetséges, hogy a hosszabb ideig tartó 
menses relatív hiperandrogenizmusra utal ezekben a betegekben, de az is előfordulhat, hogy az egyének közötti szteroidreceptor-polimorfizmusok állnak a háttérben. Irreguláris menstruáció nem fordul elő gyakrabban a HS-betegek körében [19, 20].

Egy kutatás a HS jelentőségét vizsgálta a betegek szexuális életében. HS-ban szenvedő nők esetében gyakrabban fordulnak elő szexuális problémák, mint férfiak esetén. Meglepő, hogy számos egyéb bőrbetegség esetén nincs hasonló összefüggés. HS-ban szenvedő nőknél a szexuális diszfunkció igen jelentős negatív hatást gyakorol az életminőségre, míg férfiakban ez is kevésbé jellemző. Minden HS-val foglalkozó orvos számára kiemelten fontos, hogy a kezelés alatt a szexuális funkciókra is fokozott figyelmet fordítsanak [20].

\section{A HS képalkotó diagnosztikája}

A HS diagnózisa alapvetően a klinikai képen és a beteg anamnézisén alapszik. A képalkotó diagnosztikájáról szóló irodalom egyelőre igencsak limitált, a klinikai gyakorlatban leginkább mütétek tervezése elött alkalmazható [21]. Magas frekvenciájú ultrahangvizsgálattal változó méretű és echogenitású dermalis folyadékgyülem látható, attól függően, hogy mennyi ideje állnak fenn a HStünetek az adott lokalizációban [22]. Az aktív laesiók az acnétól nehezen különböztethetők meg, mivel egyaránt echószegény struktúrák, melyek akár a subcutan régiót is elérhetik. A gyulladt tünetek körül az epidermisben és a dermisben hypodens lineáris sávok is megfigyelhetők, melyek valószínüsíthetően az oedemát jelölik [21, 22]. Az MRI-diagnosztikával készült képeken HS esetén jellegzetes bőrvastagodás és a subcutan szövetekben induratio látható. A Tl-súlyozású képeken a laesióknak alacsony jelintenzitásuk van, T2-n és STIR-en magas; súlyos HS esetén ezek tipikusan multiplex tályogos keretet mutatnak a superficialis dermisben. Egy vizsgálat során a HS elváltozásait mammográfiával is vizsgálták, mellyel az elváltozás ugyancsak jól megítélhető volt [5, $21,23]$.

\section{Szövődmények}

A HS maradhat lokalizált, de szövődményként sepsis és távoli tályogképződés is kifejlődhet. A krónikusan fennálló, fájdalmas gyulladás fibroticus folyamatok révén az adott terület hegesedéséhez vezethet. Érintett lehet az anus, az urethra és a rectum is, kontraktúrákat és beszükült mozgást okozva, ami számos egyéb betegség kialakulását vonhatja maga után [5]. A hosszabb ideje fennálló, HS okozta lymphoedema meglehetősen ritka és a legtöbbször nem felfedezett szövődmény, melynek következménye lymphangiectasia, infekció, illetve neoplasma, úgymint lymphangiosarcoma lehet. Olyan esetet is leírtak, amelyben a krónikus HS-hoz társult lymphoedema és szekunder fibrosis kiterjedt, súlyos genitalis oedemát okozott, melyet kiterjedt mütéttel lehetett megol- dani [24, 25]. Bár a HS talaján kialakult laphámrák elófordulása meglehetősen ritka, a prognózisa rossz, ugyanis általában már csak előrehaladott állapotban kerül felismerésre. Általánosságban elmondható, hogy 20-30 éve fennálló krónikus HS talaján fejlődhet ki. Kiemelendő az is, hogy a HS-betegek esetében a meglévő humánpapillomavírus (HPV)-fertózés komoly rizikófaktor a laphámrák kialakulásában [2, 26-28].

\section{Terápiás lehetőségek}

A HS kezelése sok türelmet és kitartást igényel, ugyanis gyakran a terápia többszöri váltása szükséges. Enyhébb esetekben elegendő lehet a helyi fertőtlenítés, a lokális készítmények használata, súlyosabb esetben azonban elengedhetetlen a szisztémás kezelés, sőt a sebészi megoldás lehetősége sem kizárt. Fontos, hogy a HS diagnózisa minél hamarabb megszülessen, a megfelelően megválasztott terápiával ugyanis elkerülhető mind a betegség súlyosbodása, mind a potenciális szövődmények kialakulása $[1,4,17]$.

\section{Lokális kezelések}

A 15\%-os rezorcinololdat lokális lemosóként használható a HS-tünetekkel érintett bőrterületeken. Jótékony hatását elsősorban Hurley I. és Hurley II. stádiumú betegekben írták le. Nemcsak antiszeptikus, hanem keratolitikus és viszketéscsillapító hatással is rendelkezik [5]. Egy 12 nőbeteget vizsgáló tanulmány a rezorcinol jótékony hatásáról számolt be, összehasonlítva korábbi (sebészi, antibiotikus) kezelésekkel. A tünetek fellángolása esetén naponta kétszer használható; a terápia naponta egy alkalommal remisszió esetén is folytatható. Mellékhatásként kontaktdermatitis, allergia felléphet [5, 29]. A szisztémás toxicitas lokális használatkor meglehetősen ritka, de előfordulhat. Jelenleg nem áll rendelkezésre adat a rezorcinol terhességben való alkalmazásáról [30, 31]. Hazánkban a rezorcinol nem érhető el, de saját tapasztalatunk alapján más bőrfertőtlenítő oldat, mint az Octenisept alkalmazása is előnyös.

A HS terápiájában az egyetlen, bizonyítottan hatásos lokális antibiotikum a klindamicin. Egy 27 beteget felölelő vizsgálat során azt találták, hogy a lokális klindamicin hatékonynak bizonyult olyan felületes elváltozásokban, mint a folliculitis, a pustulák és a papulák, ám a mélyebben fekvő csomókra, abscessusokra meglehetősen csekély a hatása. A mellékhatás a szisztémás kezeléshez képest ritkább, allergiával azonban számolnunk kell, illetve nem elhanyagolható probléma a baktériumrezisztencia kialakulásának veszélye sem. A lokális klindamicinkezelést átlagosan 3 hónapig kell adni, szükség esetén tovább folytatható $[4,30]$.

A lokális kortikoszteroidok közül $5-10 \mathrm{mg} / \mathrm{ml}$ intralaesionalis triamcinolon alkalmas lehet az akut fellángolások enyhítésére. Mind monoterápiában, mind adjuvánsként alkalmazható szisztémás terápia mellé [5]. 
Amennyiben a kezelés hatásos, a tünetek 48-72 órán belül enyhülést mutatnak. Alkalmazása kontraindikált abban az esetben, ha a bakteriális szuperinfekció gyanúja felmerül. Lokális mellékhatásként bőratrófia, pigmenteltérések és teleangiectasia alakulhat ki. Szisztémás mellékhatások általában az ajánlott dózis alkalmazása mellett nem jelentkeznek $[5,30,31]$.

\section{Szisztémás kezelés}

Napi $2 \times 500 \mathrm{mg}$ orális tetraciklin jótékony hatásáról számoltak be Hurley I. és II. esetén. E vizsgálat 4 hónapig tartott, de szükség szerint a terápia folytatható [32]. A tetraciklin kifejezett fényérzékenységet okoz, így szedése alatt a direkt napfény kerülése fokozottan ajánlott. A gyógyszer terhességben, valamint 9 év alatti gyerekeknek kontraindikált, ugyanis csont- és fogfejlődési zavart okozhat. Csökkent vesemúködés esetén mellékhatásként felléphet hepatotoxicitas, hyperphosphataemia, azotaemia és acidosis is $[8,32,33]$.

Klindamicin-rifampicin kombináció a HS bármelyik stádiumában alkalmazható. A terápiás dózis 300 g klindamicin $600 \mathrm{mg}$ rifampicinnel kombinálva, naponta kétszer [33-35]. Egy vizsgálatban részt vevő betegek többsége 10 hét után jelentős állapotjavulásról számolt be. Ugyanakkor egyes esetekben igen masszív gastrointestinalis mellékhatások jelentkeztek. Gener és mtsai 70 páciense közül 10 számolt be mellékhatásokról a 10 hetes kezelés során, közülük 8 a terápia abbahagyására kényszerült [33]. Van der Zee és mtsai szintén súlyos mellékhatásokról számolnak be 34 páciensből 14-nél, közülük 9 betegnél állították le a gyógyszer adását [29]. A legtöbbjük hasmenésre panaszkodott, előfordult hányás és szédülés, valamint két betegnél Candida okozta vaginitis. A klindamicin a magzati hatásai szerint a B kategóriába tartozik, ami azt jelenti, hogy alkalmazása esetén a magzati ártalom lehetősége nem igazolt, de teljes bizonyossággal nem zárható ki [32]. A rifampicin ezzel szemben a $\mathrm{C}$ kategóriába sorolandó, mely szerint egyértelmű a károsító hatás, így terhesség során feltétlenül kerülendő. A rifampicin kiválasztódik az anyatejbe, azonban mellékhatásról nem számoltak be a szoptatás alatt. Jelentős enziminduktor, ezért számos gyógyszer-interakció kiváltója lehet. Ezek mellett számos egyéb antibiotikum is felmerült mint alternatíva, de ezek alkalmazásáról egyelőre nem rendelkezünk kellő bizonyítékkal [4, $31,32]$.

A szisztémás kortikoszteroidok HS-ban való alkalmazásáról egyelőre kevés klinikai adat áll rendelkezésre. Rövid távú terápiával csökkenthető a gyulladás, így uralhatók az akut fellángolások. Hosszú távú alkalmazása azonban a számos ismert mellékhatás miatt nem ajánlott. Fokozott körültekintést igényel a terhesség alatt történő alkalmazása a magzat mellékvesekéreg-szuppressziójának kockázata miatt. A tünetek fellángolására 0,5-0,7 $\mathrm{mg} / \mathrm{kg}$ orális prednizolon javasolt, majd gyorsan csökkentve a dózist, néhány hét alatt leépítve használatos.
Néhány tanulmány megemlíti a szintén rövid távú, átmeneti terápiaként alkalmazható hidrokortizont, dexametazont is. A szteroidok számos, egyéb területekről már jól ismert kockázatain kívül fontos kiemelni, hogy a terápia abbahagyásakor a tünetek ismét fellángolhatnak $[3,4]$.

A dapszon antibakteriális és gyulladáscsökkentő hatással rendelkező gyógyszer, mely a HS enyhébb, Hurley I. és II. stádiumú formájában jöhet szóba másodvonalas kezelésként, terápiarezisztens esetekben. Számos esetben kontraindikált, ezek közé tartozik a G6PD-deficientia, a szulfonamidallergia, az anaemia, valamint az akut porphyria. Trimetoprimmal és rifampicinnel gyógyszerinterakció előfordulhat. Bár átjut a placentán, a dapszon nem teratogén vegyület, azonban neonatalis haemolysisról és methaemoglobinaemiáról szóló adatok ismeretesek a harmadik trimeszterben történő alkalmazásakor. Szoptatáskor a dapszonterápia kerülendő [29]. Terápiás dózisa 25-200 mg naponta, a magasabb dózis adását a szisztémás és a hematológiai mellékhatások limitálhatják $[4,30]$.

A ciklosporin A egy kalcineurininhibitor, mely immunszuppresszív aktivitással rendelkezik; fó célpontjai a T-lymphocyták, alkalmazásakor mind a proliferációjuk, mind a lymphokintermelésük csökken. A keratinocytákra kifejtett hatása azonban a T-sejt-hatástól független. A ciklosporin A jótékony hatásairól szóló tanulmányok meglehetősen limitáltak, így nem első vonalbeli terápia. Klinikai vizsgálatokban $2-6 \mathrm{mg} / \mathrm{kg}$ ciklosporin A-t használtak változó időtartamig ( 6 héttől 7 hónapig). Fő mellékhatások a vesetoxicitas, a magas vérnyomás és a megnövekedett rizikó különböző malignus folyamatok kialakulására. Emellett gastrointestinalis mellékhatások, gingiva hyperplasia, tremor, májfunkcióromlás, myalgia, paraesthesia, fáradtság, hyperlipidaemia, hypertrichosis, hyperkalaemia, hypomagnesaemia és hyperurikaemia fordulhat elő [29].

Antiandrogén hormonok, például a ciproteron-acetát, valamint ösztrogének javíthatnak a betegség lefolyásán, ugyanakkor a progeszteron ronthat, sőt elő is idézheti a HS tüneteit az androgénszerú hatásai miatt. Az antiandrogén hormonok, valamint ösztrogének alkalmazása indokolt lehet olyan nők esetében, akiknél menstruációs zavarok, hiperandrogenizmus vagy emelkedett szérumDHEAS-, -androszténdion-, esetleg -kötőfehérje-szint áll fenn, terhességben azonban kontraindikáltak. Antiandrogén, $100 \mathrm{mg} /$ nap ciproteron-acetát és etinilösztradiol kombinált terápia alkalmazása a vizsgált nőbetegek mindegyikében nagymértékben enyhítette a tüneteket, azonban az antiandrogén dózisát $50 \mathrm{mg} /$ napra csökkentve ismét állapotromlás jelentkezett. Mindemellett közlemények beszámolnak antikoncipienst kapó nőknél állapotjavulásról [5].

A retinoidok közül az izotretinoin korábban elterjedten került alkalmazásra, mára a hatékonysága kérdőjelessé vált. Részleges jótékony hatása a HS-ban annak tulajdonítható, hogy meggátolja a szőrtüszők hyperkeratosisából adódó okklúziót. Ugyanakkor egyes antiinflam- 
matoricus komponenseket is kimutattak, melyek valószínűsíthetően a monocyták kemotaxisának befolyásolásán keresztül valósulnak meg. A terápia elkezdése előtt kötelezően ellenőrizendők a páciens májenzim-, valamint lipidszintjei, továbbá tájékoztatnunk kell betegünket arról, hogy a terápia alatt szigorúan tilos teherbe esnie [36]. Abban az esetben, ha a beteg említett laborértékei kétszer vagy háromszor a normálérték fölé kerülnek, a terápia abbahagyandó. A terápia ideje alatt rendkívül fontos a fogamzásgátlás, hiszen a retinoidok az egyik legveszélyesebb teratogén gyógyszerek. A fogamzásgátlás mellett nagyon fontos a páciens megfelelő tájékoztatása, a betegedukáció, valamint a rendszeres kontroll is. Általánosságban a terápia megegyezik az izotretinoin acne vulgarisban történő alkalmazásával [37]. Egy 174 föt felölelő vizsgálatban napi $0,5-1,2 \mathrm{mg} / \mathrm{kg}$ dózist alkalmazva 4-12 hónapon keresztül jó terápiás hatás volt elérhető. Alkalmazásáról nincs egyértelmű konszenzus, általánosan nem ajánlott terápiának számít a HS kezelésében. Mivel mind az izotretinoin, mind a tetraciklinek intracranialis nyomásfokozódást okozhatnak, kombinálásuk kontraindikált $[29,32,33]$. Az acitretin az etretinát effektívebb, rövidebb felezési idejű metabolitja, mely számos bőrbetegségben használatos. Segít normalizálni a sejtdifferenciálódást, csökkenti a keratinocyták proliferációját, valamint gyulladásgátló hatáskomponenssel is rendelkezik. Indikációja és kontraindikációi megegyeznek az izotretinoinéval. A $0,8-1,25 \mathrm{mg} / \mathrm{kg}$ dózisú acitretinkezelést 3-12 hónap időtartamig javasolt alkalmazni [29].

\section{Biológiai terápia}

A TNF $\alpha$-antagonista biológiai szerek közül az adalimumab és az infliximab rendkívül hatékonynak bizonyult a HS közepes és súlyos formájának kezelésében. Az adalimumab teljesen humanizált antitest, ezért kevesebb mellékhatással rendelkezik. A terápia elkezdése előtt ki kell zárni egy esetleges akut infekció, tuberkulózis, HIV vagy vírusos hepatitis jelenlétét $[30,33]$. Fontos kiemelni, hogy míg korábban terhességben és szoptatásban kontraindikált volt, mára az összegyưlt irodalmi adatok szerint az első két trimeszterben adható, alkalmazását csak a harmadik trimesztertől kell kerülni. Abszolút kontraindikációt jelent még a NYHA III-IV. stádiumú szívelégtelenség, a súlyos májbetegség, a demyelinisatiós kórképek és a malignus daganatok. A terápia 0 . napján 160 mg kezdő dózist kell adni, majd egy héttel később $80 \mathrm{mg}$, fenntartó kezelésként $40 \mathrm{mg}$ adalimumab adandó egy héten egyszer, subcutan injekció formájában. Számos tanulmány ismeretes, amelyben szignifikáns javulást írtak le a betegek jelentős részében [29]. Különösen azoknak a közepes vagy súlyos HS-ban szenvedőknek az esetében megfontolandó az alkalmazása, akiknél az antibiotikumterápia hatástalannak bizonyul. Mellékhatása, hogy megnövekszik a különböző infekciókra való hajlam; olyan súlyosabb kórképek is leírásra kerültek, mint a pneumonia, a szeptikus arthritis, az erysipelas vagy a pyelonephritis. Ritkán, de autoantitestek (ANA, anti-dsDNA) megjelenhetnek a szérumban, lupusszerú kórképet okozva. Nagyon ritkán kialakulhatnak malignus daganatok, különösen lymphomák [29, 30, 33, 37].

Az infliximab egy kiméra (egér/humán) antitest, használata indikáción túli alkalmazásnak számít. Az adalimumabéival azonosak a kontraindikációi is. Nem tisztán humán eredetű volta miatt az immunválasz kialakulásának valószínüsége nagyobb, ezért először elnyújtott, 2 órás infúzióban kell adni; ha ekkor nem tapasztalunk immunválaszt, ez l órára csökkenthető [29]. Fontos, hogy az infúzió beadása után további 1 óráig monitorozni kell a beteget a szövődmény kialakulásának elkerülése érdekében. Anafilaxiás reakció előfordulhat, mely antihisztamin adásával kezelendő. Alacsony dózisú metotrexát (5-10 mg/hét) alkalmazásával az infliximabellenes antitestek száma csökkenthető. Az infúzió további mellékhatása lehet fejfájás, hányás, kipirulás, nehézlégzés. Hoszszan tartó kezelés során kialakulhat arthralgia, myalgia és angiooedema [29, 30, 33].

\section{Fájdalomcsillapítás}

A HS krónikus, nagy fájdalmakkal járó betegség, melyet az összefekvő területek irritációja és a külső elváltozások miatt kialakult szégyenérzet tovább ronthat, jelentősen rontva ezáltál a betegek életminőségét. A heves és meglehetősen intenzív fájdalom ellenére a HS fájdalomcsillapításával a jelen irodalomban ritkán találkozhatunk.

A nemszteroid gyulladásgátlók (nonsteroidal anti-inflammatory drugs, NSAID) széles körben elterjedt gyógyszereknek számítanak fájdalom- és lázcsillapító hatásuknak köszönhetően, nagyobb dózisban alkalmazva gyulladáscsökkentő hatás is elérhető $[29,30]$. Mellékhatás lehet vérzés, kialakuló fekélybetegség, szalicilátok esetén köszvény, vesefunkció-romlás, valamint a szelektív COX2-izoenzim-gátlók esetében kiemelendő a fokozott cardiovascularis kockázat a lehetséges thrombemboliás szövődmények miatt, ezért az ilyen rizikócsoportba tartozó betegek esetében a coxibok kerülendők [38]. A NSAID-csoportba tartozó gyógyszerek szülészeti vonatkozásaként megemlítendő, hogy méhrelaxációt okoznak, továbbá a harmadik trimeszterben a magzat Botallo-vezetékét idő előtt zárják, emiatt terhesség alatt kontraindikáltak, de legalábbis nagy elővigyázatossággal alkalmazható gyógyszernek számítanak [35].

Az opioidok mind a centrális, mind a perifériás idegrendszerben megtalálható, úgynevezett opioid receptorokhoz kötve jelentős módon képesek a fájdalom csillapítására; major, vagy más néven kábító fájdalomcsillapítóknak is nevezzük őket. A receptor-ligand kötés során a fájdalom - mint emocionális szenzoros válaszreakció keletkezése, transzmissziója, centrális transzformációja, egyebekben tudatosulása is gátlás alá kerül. A legelterjedtebb opioid fájdalomcsillapítók a hidrokodon, az oxikodon, a morfin és a kodein [29]. Ezek a fájdalomcsilla- 
pítók magzati hatásaik szerint a $\mathrm{C}$ kategóriába tartoznak, ami azt jelenti, hogy a magzati ártalom lehetősége nem zárható ki, azonban a terhesség alatti alkalmazásból származó előny egyértelműen magasabb a lehetséges kockázatnál. Használatuk fokozott körültekintést igényel. Rövid ideig alkalmazhatók a posztoperatív szakaszban, illetve intenzív fájdalom esetén, de csak az első trimeszter után. Szoptatás alatt használatuk kerülendő, ugyanis az anyatejjel a csecsemőbe jutva jelentős centrális légzésdepressziót okozhatnak. Tramadol alkalmazása esetén a csecsemő expozíciója minimális, ezért ezt tartják a legoptimálisabb választásnak a szoptatás ideje alatt. Az opioidok kontraindikációi közé tartozik a koponyaúri nyomásfokozódás, az asztma, a cor pulmonale, a máj- és vesemúködési zavarok, valamint az epilepszia is [30, 39].

\section{Mentális egészség}

Mindamellett, hogy kezelőorvosként elsősorban a fizikai tünetek enyhítésére törekszünk, rendkívül fontos a beteg mentális egészségének megőrzése is. Több vizsgálat szerint a HS-ban szenvedő nőknél nagyon gyakran fordulnak elő a depresszió tünetei, sőt a klinikai depresszió és a generalizált szorongás előfordulása is gyakori [29, 40]. Konkrét ajánlás a mentálhigiéné megőrzésével kapcsolatban nem áll rendelkezésre, de támogató csoportok, pszichológus szakember bevonása a terápiába mindenképpen hasznos lehet. Terhes nókben a post partum depresszió akár ronthat is a meglévő tüneteken, ezért az ő esetük kiemelt odafigyelést igényel a klinikus részéről. Amennyiben szükséges, a beteg terápiája kiegészíthető hangulatstabilizálókkal, antidepresszánsokkal, ez azonban nem helyettesítheti a beteg pszichés vezetését [29, 41].

\section{Sebészi kezelés}

Tekintve, hogy a gyógyszeres kezelés HS esetén önmagában ritkán vezet tartós javuláshoz, és a teljes gyógyulás nem érhető el, sok esetben a sebészi beavatkozás az a választandó terápia a HS kezelésében, amellyel tartós, sokszor végleges remissziót érhetünk el. Különböző típusai kombinációban is végezhetők, melyek alkalmazását a betegség súlyossága, kiterjedtsége és lokalizációja határozza meg [25].

A konvencionális sebészi terápia önmagában több módszert foglal magában, szimpla excisiót vagy kürettázst, széles kimetszést, valamint a rekonstrukció több típusát. A parciális excisiót olyan esetekben használják, amikor egy szoliter laesio kezeléséről van szó, azonban közel 70\%-ban újra megjelennek a tünetek a kezelt lokalizációban $[25,42]$. A sebészi incisio csak sürgősségi ellátásként végzendő a HS kezelésében, az akut feszülő tályog azonnali megoldására, kuratív hatása a betegségre nincsen. Így a legtöbb ajánlás inkább a széles excisiót javasolja, mely magában foglalja az apokrin mirigyeket tartalmazó bőrfelületeket és a környezetükben lévő, szőrrel fedett bőrréteget is. A sebészi terápia része az érintett bőr és az alatta lévő szövetek teljes eltávolítása minden esetben, azonban a rekonstrukció nem képezi egységes részét az irányelveknek [42]. Rompel és mtsai vizsgálata szerint a rekonstrukció típusának nincs hatása a kiújulásra, és emiatt az eltávolított terület méretére és lokalizációjára való tekintettel kell a módját megválasztani [43]. Típusai között szerepel az az ellátási forma, amikor nem csinálnak rekonstrukciót, és a másodlagos gyógyulásra bízzák a terület bezárását. Máskor szimpla öltésekkel zárják a bőrt, ugyanakkor a leggyakoribb a félvastag bőrgraft alkalmazása, amely lehet azonnali, késleltetett és második ülésben végzett beavatkozás is. Nem utolsósorban lebeny (myocutan) plasztika/rekonstrukció is végezhető, azonban ebben az esetben a kiújulás valószínúsége magasabb, mint a félvastag bőrgraft alkalmazása esetében [42].

A bőrgyógyászati sebészetben ma az egyik legelterjedtebb és igen hatékony eljárás az úgynevezett deroofing, amelyet azonban csak a Hurley I. és ritkább esetekben a Hurley II. stádium enyhébb formáiban alkalmaznak a fájdalmas, feszülő csomók és kezdődő tályog ellátása esetén. Deroofing végzését követően a váladékozó, rendkívül fájdalmas laesióból egy kozmetikailag is elfogadható heg marad meg. A deroofing nagy előnye, hogy a lehető legtöbb egészséges szövet megőrzése mellett végezhető. A beavatkozás előtt tintával jelölik az elváltozásokat, mely körül fertőtlenítést követően lokális lidokainos érzéstelenítésben elektrokauterrel végzik a deroofingot $[42,44]$. A kezelés természetesen a betegség súlyosságától függ. Egy klinikai vizsgálat szerint deroofing végzését követően 88 HS-betegből csak 15-nél tért vissza a betegség azonos lokalizációban, így 83\%-ban gyógyulás volt elérhető az eljárással [42, 45].

A súlyosabb, Hurley II. és III. stádiumban a HS sebészi kezelése a mai napig meglehetősen nehéz, más megközelítést igényel. Az összetett kezelés első lépése a gyulladásgátlás, mely szisztémásan immunszupprimánsokkal történik. Ezekben a stádiumokban a HS kezelésében elengedhetetlen a sinusjáratok és a fibroticus hegek eradikációja is, mely így a sebészeti ellátás alapvető része [42, 46]. Ezekben az esetekben az úgynevezett STEEP-technika (skin-tissue-sparing excision with electrosurgical peeling) választandó, mely lokális vagy általános anesztéziában is végezhető. Az eljárás az érintett terület alapos áttapintásával indul, a gyulladásos csomók lokalizálása érdekében. A látható sinusjáratokat meg kell szondázni, hogy kiterjedtségük felmérhető legyen. Minden érintett gyulladt, fibroticus szövetet, melyet előzőleg kitapintottunk, el kell távolítani egészen a mélyebb bőrrétegekig. Ahol lehetséges, a sinusok hámmal borított alapját, valamint a subcutan zsírszövetet meg kell hagyni [46]. Végül a sebszéleket aprólékosan át kell vizsgálni az esetleges residualis sinusjáratok eltávolítása céljából. A STEEP-et követően a sebet nyitva kezeljük. A posztoperatív sebkezelés algináttal és szilikonos kötszerrel végzendő. A fájdalomcsillapítás NSAID-szerekkel, súlyos esetben opioidokkal történik. A STEEP-mütét általában nem igényel 
hospitalizációt, a betegek a mütét napján vagy másnapján hazabocsáthatók $[33,46]$.

A HS invazív kezelésének legújabb módszerei a lézerkezelések, melyeknek nagy előnye, hogy a HS-laesiókat képesek belülről kifelé haladó irányban vaporizálni, amíg a környező egészséges szöveteket el nem érik, így ezek a technikák egyben szövetmegtartók és radikálisak is. Ezek a módszerek kevesebb vérzéssel és jobb vizualizációval is járnak a sebészi módszerekhez képest [33, 47-49]. Azonban a lézerkezelések alkalmazhatósága a betegség súlyosságával fordítottan arányos. Kiemelt jelentőségű tehát a HS lézerkezelésében az időzítés. A lehető leghamarabb kell elvégezni a beavatkozást, ugyanis a betegség legsúlyosabb formáiban egyedül a széles sebészi kimetszés nyújthat megoldást [48].

A HS kezelésében szelektív és ablatív hatású lézerek egyaránt alkalmazhatók. Szelektív lézer a Nd:YAG, mely Hurley I. és II. stádiumban hatékony azáltal, hogy alkalmazásával az érintett területen csökkenthető a szőrtüszők és az apokrin verejtékmirigyek száma [47]. Annak érdekében, hogy minimalizáljuk a terápia okozta szövetkárosodást, valamint növeljük a penetráció mélységét, a hosszabb hullámhosszok választandók. A leghatásosabbnak a $1064 \mathrm{~nm}$ hullámhossz bizonyult [49]. Az ablatív úton ható, $10600 \mathrm{~nm}$ hullámhosszú szén-dioxid-lézer az egész érintett szövetterületet - beleértve a sinusjáratokat is - képes eltávolítani. Emiatt Hurley III. stádiumban használható a klasszikus sebészeti megoldások alternatívájaként. Alkalmazásakor a nem érintett környező szövet megkímélhető. Vérzéscsillapító tulajdonságának köszönhetően javul az operációs terület átláthatósága is, továbbá a sebgyógyulás feltételei is kedvezőbbek [48]. Vivek Jain és Archana Jain egy kis elemszámú vizsgálatban a Nd:YAG, illetve a szén-dioxid-lézert kombinálva rendkívül jó terápiás hatásról számolt be. Négy, 30-40 év közötti nőbetegen alkalmazva e technikát, 3 éves betegkövetés után egyikükben sem újult ki a betegség [50]. A HS lézerkezelésének további előnye, hogy nem igényel általános anesztéziát vagy tartós kórházi bennfekvést, a beteg 4-5 napon belül ismét munkába állhat [ 49 , 50]. A HS lézerkezelése, bár viszonylag új terápiás módszernek számít, a terápiás arzenálba jól beilleszthető. Jelentősen javítja a betegek életminőségét azáltal, hogy mind a fájdalom, mind a gyógyulási idő csökken, és sok esetben a betegség tartós remissziója érhető el [47-50].

\section{Következtetés}

Mint látható, a HS kezelésével kapcsolatban számos klinikai vizsgálat történt az utóbbi években. Több gyógyszer jó terápiás hatásáról is beszámoltak, azonban az esetek többségében a terápia többszöri váltására is szükség van. A kezelés kiválasztásakor nem elég a HS súlyossága alapján mérlegelnünk, ügyelnünk kell a beteg egyéb társbetegségeire, valamint egy esetlegesen fennálló terhességre, ilyenkor ugyanis nem minden elérhető szer választható. Korai stádiumban mindenekelőtt a megfelelő higiéniát, a testsúly rendezését, a dohányzásról való leszokást kell hangsúlyozni a betegeknek. A gyógyszeres terápia során különböző antiszeptikumok, kortikoszteroidok és szisztémás antibiotikumok alkalmazandók, valamint súlyos esetekben a biológiai terápia is szóba jöhet. A sebészi kezeléssel ugyan tartós eredményeket lehet elérni, számolni kell az elhúzódó sebgyógyulással. Laphámrák gyanúja esetén biopsziás mintavétel végzendő. A HS kezelésének egy új iránya a lézerkezelés, melynek kedvező terápiás hatásáról egyre több irodalmi adat áll rendelkezésre [2, 26, 47-50].

Anyagi támogatás: A közlemény megírása, illetve a kapcsolódó kutatómunka anyagi támogatásban nem részesült.

Szerzôi munkamegosztás: K. N.: Irodalomkutatás, szövegírás, az egyes szerzők által írt részek szintetizálása. P. D., L. K., B. A.: Irodalomkutatás, szövegírás, szerkesztés. V. S., W. N.: A leírtak áttekintése, azok helyességének ellenőrzése, értékes szakmai tanácsadás és kiegészítések. A cikk végleges változatát valamennyi szerző elolvasta és jóváhagyta.

Érdekeltségek: A szerzőknek nincsenek érdekeltségeik.

\section{Irodalom}

[1] Papp Z. Textbook of obstetrics and gynaecology. [A szülészetnőgyógyászat tankönyve.] Semmelweis Kiadó, Budapest, 2017. [Hungarian]

[2] Rekawek P, Mehta S, Andikyan V, et al. Squamous cell carcinoma of the vulva arising in the setting of chronic hidradenitis suppurativa: a case report. Gynecol Oncol Rep. 2016; 16: 28-30.

[3] Meixner D, Schneider S, Krause M, et al. Acne inversa. J Dtsch Dermatol Ges. 2008; 6: 189-196.

[4] Dufour DN, Emtestam L, Jemec GB. Hidradenitis suppurativa: a common and burdensome, yet under-recognised, inflammatory skin disease. Postgrad Med J. 2014; 90: 216-221.

[5] Newman TM, Sheth MM, Levy A, et al. Hidradenitis suppurativa: mammographic and sonographic manifestations in two cases. Radiol Case Rep. 2013; 8: 737.

[6] Nevitt GJ, Hutchinson PE. Psoriasis in the community: prevalence, severity and patients' beliefs and attitudes towards the disease. Br J Dermatol. 1996; 135: 533-537.

[7] Ring HC, Theut Riis P, Zarchi K, et al. Prodromal symptoms in hidradenitis suppurativa. Clin Exp Dermatol. 2017; 42: 261265.

[8] Dauden E, Lazaro P, Aguilar MD, et al. Recommendations for the management of comorbidity in hidradenitis suppurativa. J Eur Acad Dermatol Venereol. 2018; 32: 129-144.

[9] Vilanova I, Hernández JL, Mata C, et al. Insulin resistance in hidradenitis suppurativa: a case-control study. J Eur Acad Dermatol Venereol. 2018; 32: 820-824.

[10] Principi M, Cassano N, Contaldo A, et al. Hydradenitis suppurativa and inflammatory bowel disease: an unusual, but existing association. World J Gastroenterol. 2016; 22: 4802-4811.

[11] Matusiak Ł, Bieniek A, Szepietowski JC. Hidradenitis suppurativa and associated factors: still unsolved problems. J Am Acad Dermatol. 2009; 61: 362-365.

[12] Blok JL, Li K, Brodmerkel C, et al. Ustekinumab in hidradenitis suppurativa: clinical results and a search for potential biomarkers in serum. Br J Dermatol. 2016; 174: 839-846. 
[13] Karagiannidis I, Nikolakis G, Zouboulis CC. Endocrinologic aspects of hidradenitis suppurativa. Dermatol Clin. 2016; 34: 4549.

[14] Harrison BJ, Read GF, Hughes LE. Endocrine basis for the clinical presentation of hidradenitis suppurativa. Br J Surg. 1988; 75 972-975.

[15] Harrison BJ, Kumar S, Read GF, et al. Hidradenitis suppurativa: evidence for an endocrine abnormality. Br J Surg. 1985; 72: 1002-1004

[16] Karagiannidis I, Nikolakis G, Sabat R, et al. Hidradenitis suppurativa/acne inversa: an endocrine skin disorder? Rev Endocr Metab Disord. 2016; 17: 335-341.

[17] Dessinioti C, Katsambas A, Antoniou C. Hidradenitis suppurrativa (acne inversa) as a systemic disease. Clin Dermatol. 2014; 32: 397-408

[18] Perng P, Zampella JG, Okoye GA. Management of hidradenitis suppurativa in pregnancy. J Am Acad Dermatol. 2017; 76: 979989.

[19] Perng P, Zampella JG, Okoye GA. Considering the impact of pregnancy on the natural history of hidradenitis suppurativa. $\mathrm{Br}$ J Dermatol. 2018; 178: el3-el4.

[20] Kurek A, Peters EMJ, Chanwangpong A, et al. Profound disturbances of sexual health in patients with acne inversa. J Am Acad Dermatol. 2012; 67: 422-428.

[21] Wortsman X. Imaging of hidradenitis suppurativa. Dermatol Clin. 2016; 34: 59-68.

[22] Wortsman X, Castro A, Figueroa A. Color Doppler ultrasound assessment of morphology and types of fistulous tracts in hidradenitis suppurativa (HS). J Am Acad Dermatol. 2016; 75: 760 767.

[23] Kelly AM, Cronin P. MRI features of hidradenitis suppurativa and review of the literature. Am J Roentgenol. 2005; 185: 1201-1204.

[24] Moosbrugger EA, Mutasim DF. Hidradenitis suppurativa complicated by severe lymphedema and lymphangiectasias. J Am Acad Dermatol. 2011; 64: 1223-1224.

[25] Faye O, Petit F, Poli F, et al. Lymphedema as a complication of hidradenitis suppurativa in three patients. Ann Dermatol Venereol. 2007; 134: 567-569.

[26] Short KA, Kalu G, Mortimer PS, et al. Vulval squamous cell carcinoma arising in chronic hidradenitis suppurativa. Clin Exp Dermatol. 2005; 30: 481-483.

[27] Sims SM, McLean FW, Davis JD, et al. Vulvar lymphangioma circumscriptum: a report of 3 cases, 2 associated with vulvar carcinoma and 1 with hidradenitis suppurativa. J Low Genit Tract Dis. 2010; 14: 234-237.

[28] Lavogiez C, Delaporte E, Darras-Vercambre S, et al. Clinicopathological study of 13 cases of squamous cell carcinoma complicating hidradenitis suppurativa. Dermatology 2010; 220: 147-153.

[29] Zouboulis CC, Desai N, Emtestam L, et al. European S1 guideline for the treatment of hidradenitis suppurativa/acne inversa. J Eur Acad Dermatol Venereol. 2015; 29: 619-644.

[30] Saunte DM, Jemec GB. Hidradenitis suppurativa: advances in diagnosis and treatment. JAMA 2017; 318: 2019-2032.

[31] Robert E, Bodin F, Paul C, et al. Non-surgical treatments for hidradenitis suppurativa: a systematic review. Ann Chir Plast Esthet. 2017; 62: 274-294

[32] Jemec GBE, Wendelboe P. Topical clindamycin versus systemic tetracycline in the treatment of hidradenitis suppurativa. J Am Acad Dermatol. 1998; 39: 971-974.

[33] Gener G, Canoui-Poitrine F, Revuz JE, et al. Combination therapy with clindamycin and rifampicin for hidradenitis suppurativa: a series of 116 consecutive patients. Dermatology 2009; 219: $148-154$.

[34] Mendonca CO, Griffiths CE. Clindamycin and rifampicin combination therapy for hidradenitis suppurativa. Br J Dermatol. 2006; 154: 977-978.

[35] Gulliver W, Zouboulis CC, Prens E et al. Evidence-based approach to the treatment of hidradenitis suppurativa/acne inversa, based on the European guidelines for hidradenitis suppurativa. Rev Endocr Metab Disord. 2016; 17: 343-351.

[36] Browne H, Mason G, Tang T. Retinoids and pregnancy: an update. Obstetric Gynaecol. 2014; 16: 7-11.

[37] Amano M, Grant A, Kerdel FA. A prospective open-label clinical trial of adalimumab for the treatment of hidradenitis suppurativa: adalimumab for treating hidradenitis suppurativa. Int J Dermatol. 2010; 40: 950-955.

[38] Kearney PM, Baigent C, Godwin J, et al. Do selective cyclo-oxygenase-2 inhibitors and traditional non-steroidal anti-inflammatory drugs increase the risk of atherothrombosis? Meta-analysis of randomised trials. BMJ 2006; 332: 1302-1308.

[39] Ring HC, Theut Riis P, Miller IM, et al. Self-reported pain management in hidradenitis suppurativa. Br J Dermatol. 2016; 174: 909-911.

[40] Onderdijk AJ, van der Zee HH, Esmann S, et al. Depression in patients with hidradenitis suppurativa: depression in HS patients. J Eur Acad Dermatol Venereol. 2013; 27: 473-478.

[41] Patel ZS, Hoffman LK, Buse DC, et al. Pain, psychological comorbidities, disability, and impaired qualify of life in hidradenitis suppurativa. Curr Pain Headache Rep. 2017; 21: 49. Erratum Curr Pain Headache Rep. 2017; 21 : 52.

[42] Ruan QZ, Chen AD, Singhal D, et al. Surgical management of hidradenitis suppurativa: procedural trends and risk factors. J Surg Res. 2018; 229: 200-207.

[43] Rompel R, Petres J. Long-term results of wide surgical excision in 106 patients with hidradenitis suppurativa. Dermatol Surg. 2000; 26: 638-643.

[44] Mandal A, Watson J. Experience with different treatment modules in hidradenitis suppuritiva: a study of 106 cases. Surgeon 2005; 3: 23-26.

[45] van Hattem S, Spoo JR, Horváth B, et al. Surgical treatment of sinuses by deroofing in hidradenitis suppurativa. Dermatol Surg. 2012; 38: 494-497.

[46] Deckers IE, Dahi Y, van der Zee HH, et al. Hidradenitis suppurativa treated with wide excision and second intention healing: a meaningful local cure rate after 253 procedures. J Eur Acad Dermatol Venereol. 2018; 32: 459-462.

[47] John H, Manoloudakis N, Sinclair JS. A systematic review of the use of lasers for the treatment of hidradenitis suppurativa. J Plast Reconstr Aesthetic Surg. 2016; 60: 1374-1381.

[48] Hamzavi IH, Griffith JL, Riyaz F, et al. Laser and light-based treatment options for hidradenitis suppurativa. J. Am Acad Dermatol. 2015; 73: 78-81.

[49] Abdel Azim AA, Salem RT, Abdelghani R. Combined fractional carbon dioxide laser and long-pulsed neodymium : yttrium-aluminium-garnet $(1064 \mathrm{~nm})$ laser in treatment of hidradenitis suppurativa; a prospective randomized intra-individual controlled study. Int J Dermatol. 2018; 57: 1135-1144.

[50] Jain V, Jain A. Use of lasers for the management of refractory cases of hidradenitis suppurativa and pilonidal sinus. J Cutan Aesthet Surg. 2012; 5: 190-192.

(Wikonkál Norbert dr., Budapest, Mária u. 41., 1085 e-mail: wikonkal@gmail.com)

A cikk a Creative Commons Attribution 4.0 International License (https://creativecommons.org/licenses/by/4.0/) feltételei szerint publikált Open Access közlemény, melynek szellemében a cikk bármilyen médiumban szabadon felhasználható, megosztható és újraközölhetö, feltéve, hogy az eredeti szerző és a közlés helye, illetve a CC License linkje és az esetlegesen végrehajtott módosítások feltüntetésre kerülnek. (SID_1) 